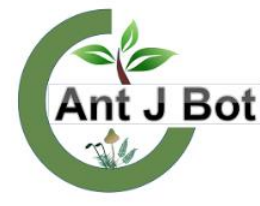

Received : 16.11 .2020 Accepted : 17.12 .2020 Online : 09.01.2021

\section{Hymenoscyphus caudatus, a new ascomycete record for the mycobiota of Turkey}

\author{
Ahmet ÇETINKAYA ${ }^{1}$, Yasin UZUN ${ }^{2 *}$ (B) \\ ${ }^{1}$ Ayranci Social Assistance and Solidarity Foundation, 70100 Karaman, Turkey \\ ${ }^{2}$ Karamanoğlu Mehmetbey University, Science Faculty, Department of Biology, Karaman, Turkey \\ *yuclathrus@gmail.com, 1ahmet_cetinkayaaa@hotmail.com
}

\section{Hymenoscyphus caudatus, Türkiye mikobiyotası için yeni bir askomiset kaydı}

Abstract: Hymenoscyphus caudatus (P. Karst.) Dennis is given as new record for the mycobiota of Turkey. The macro and micromorphological characters of the species are provided together with the localities of collection, collector numbers and the photographs related to its macro and micromorphologies.

Key words: Biodiversity, macrofungi, new record, Helotiaceae

Özet: Hymenoscyphus caudatus (P. Karst.) Dennis Türkiye için yeni kayıt olarak verilmiştir. Türün makro ve mikromorfolojik karakterleri, toplanma lokaliteleri, toplayıcı numaraları ve makro ve mikromorfolojilerine ait fotoğrafları ile birlikte verilmiştir.

Anahtar Kelimeler: Biyoçeşitlilik, makromantarlar, yeni kayıt, Helotiaceae

Citation: Çetinkaya A, Uzun Y (2021). Hymenoscyphus caudatus, a new ascomycete record for the mycobiota of Turkey. Anatolian Journal of Botany 5(1): 19-22.

\section{Introduction}

Hymenoscyphus Gray is a widespread genus within the family Helotiaceae (Ascomycota) with more than 800 species (Kirk et al., 2008). The members of the genus are generally characterized by their stipitate to sessile discoid apothecia; white to yellowish hymenial surface and subellipsoid, fusoid, or scutuloid ascospores. Species of the genus are normally saprophytic on plant debris, such as wood, twigs, fruits, leaves, and herbaceous stems. Though the known species are mainly reported from America, Asia and Europe, it is a cosmopolitan one.

Hymenoscyphus fructigenus (Bull.) Gray was the first species of the genus Hymenoscyphus to be reported in Turkey (Aktaş et al., 2006). Between the years 2009 and 2019, twelve members of the genus (H. calyculus (Fr.) W. Phillips, H. epiphyllus (Pers.) Rehm ex Kauffman, $H$. fagineus (Pers.) Dennis, $H$. herbarum (Pers.) Dennis, $H$. immutabilis (Fuckel) Dennis, H. kathiae (Korf) Baral, $H$. lepismoides Baral \& Bemmann, H. lutescens (Hedw.) W. Phillips, H. robustior (P. Karst.) Dennis, H. scutula (Pers.) W. Phillips, H. serotinus (Pers.) W. Phillips, H. umbilicatus (Le Gal) Dumont) have also been presented (Kaya, 2009; Kaya et al., 2009; Doğan and Aktaş, 2010; Öztürk et al., 2010, 2016; Uzun et al., 2010, 2014; Akata et al., 2014; Iş1k and Türkekul, 2018; Keleş, 2019a), increasing the current taxa number of the genus to 14 in Turkey.

During routine field trips in Yeşildere district of Karaman, some stipitate discoid ascomycete samples were collected. As a result of field and laboratory investigation they were identified as $H$. caudatus. Tracing the current checklists on Turkish macromycota (Sesli and Denchev, 2014; Solak et al., 2015) and the latest contributions (Berber et al., 2019; Kaya et al., 2019; Keleş, 2019b; Sesli, 2019; Türkekul and Işık, 2019; Yıldız et al., 2019; Acar et al., 2020; Akçay, 2020; Çelik et al., 2020; İleri et al., 2020), it was noticed that the taxon has not been recorded from Turkey before.
The study aims to make a contribution to the determination of the macrofungal biodiversity of the Karaman and Turkey.

\section{Materials and Method}

Hymenoscyphus samples were collected from Yeşildere village of Karaman province. The fruit bodies were photographed at their natural habitat and notes were taken about the morphological and ecological characteristics of them. Then the specimens were carried to the fungarium and dried in an air conditioned room. Microscopic studies were performed on dried specimens under a Nikon Eclipse $\mathrm{Ci}-\mathrm{S}$ trinocular light microscope. The specimens were mounted in water and Melzer reagent. The samples were identified with the help of Kimbrough and Atkinson (1972), Dumort and Carpenter (1982), Zhuang and Korf (1989), Zhuang (1995), Ellis and Ellis (1997). The collected specimens are kept at Karamanoğlu Mehmetbey University, Kamil Özdağ Science Faculty, Department of Biology, Karaman, Turkey.

\section{Results}

Fungi R.T. Moore

Ascomycota Caval.-Sm.

Helotiales Nannf. ex Korf \& Lizoň

Helotiaceae Rehm

Hymenoscyphus caudatus (P. Karst.) Dennis, Persoonia 3(1): 76 (1964)

Syn: [Helotium caudatum (P. Karst.) Velen.; Helotium scutula var. caudatum (P. Karst.) P. Karst., Peziza caudata P. Karst.]

Macroscopic and microscopic features: Apothecia 0.5-2 $\mathrm{mm}$ in diameter, scutellate, whitish-cream, disc flat to concave, hymenium white to pale yellow when young, straw-yellow to pale yellow-orange when dry; stipe 
cylindrical, broader above and tapering slightly toward the base, concolorous with the outer surface of the receptacle, some hairy at the base (Fig. 1). Asci 100-120 ×9-12.5 $\mu \mathrm{m}$, cylindrical to clavate, eight-spored, walls outlined blue in Melzer's reagent, especially at the apex. Paraphyses filiform, equal or slightly exceeding the asci, some branched at the base, septate (Fig. 2a). Ascospores 15-24 $\times$ 4-5.5 $\mu \mathrm{m}$, ellipsoid, subfusoid to ovoid, hyaline, smooth, aseptate or rarely 1-septate, generally with two large, irregular guttules and several smaller guttules (Fig. 2b).

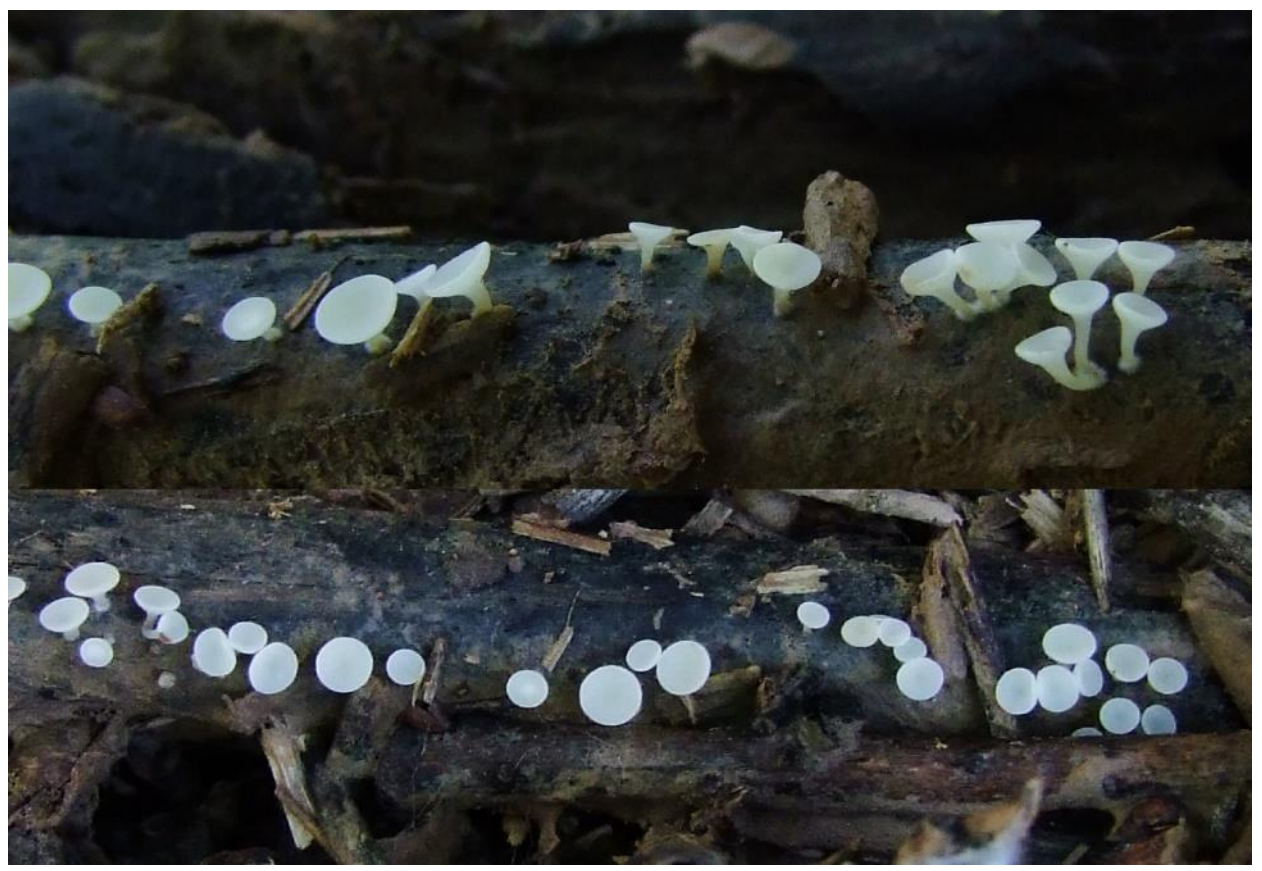

Figure 1. Ascocarps of Hymenoscyphus caudatus

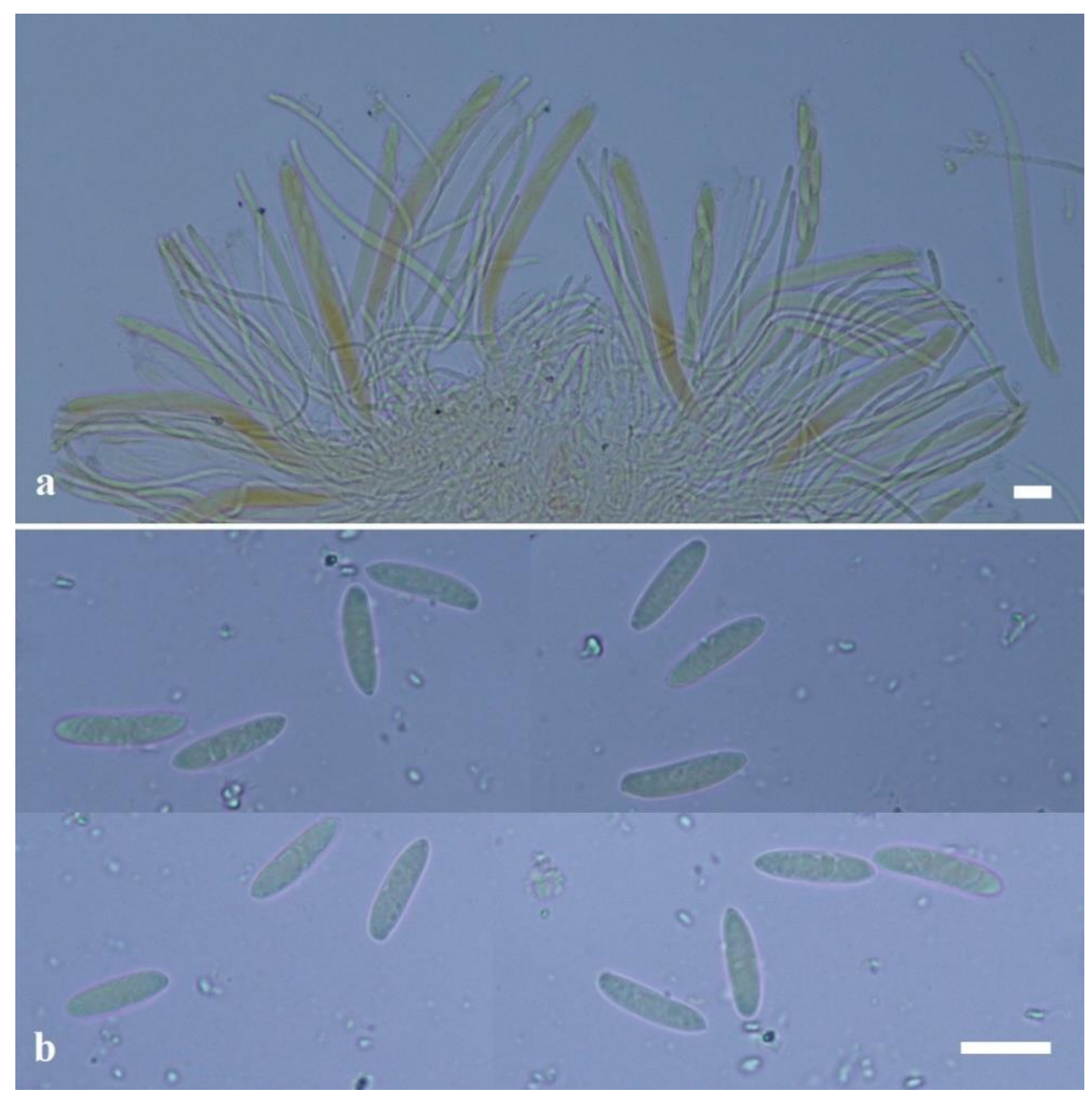

Figure 2. Asci and paraphyses (a), and ascospores of Hymenoscyphus caudatus (b) (bars: $10 \mu \mathrm{m}$ ) (a: Melzer; b: water) 
Hymenoscyphus caudatus grows on decaying leaves and leaf parts of many trees such as the members of Acer, Aesculus, Alnus, Betula, Castanea, Carpinus, Corylus, Crataegus, Fagus, Fraxinus, Pinus, Platanus, Populus, Prunus, Quercus, Robinia, Salix, Tilia, Ulmus, and rarely on herbaceous stem (Kimbrough and Atkinson, 1972; Ellis and Ellis, 1997; Zhuang, 1995).

Specimens examined: Karaman, Yeşildere village, on decaying leaves and twigs of Populus sp., $37^{\circ} 09^{\prime} \mathrm{N}-$ $33^{\circ} 29^{\prime} \mathrm{E}, 1160$ m, 07.05.2015, AÇK. 223.

\section{Discussions}

Hymenoscyphus caudatus was given as new record for Turkish mycobiota as the fourteenth member of the genus Hymenoscyphus. In general, macro and micromorphology are in agreement with those given in literature.

Hymenoscyphus caudatus was reported to be common on leaf litter and grow on decaying leaves and leaf parts of deciduous trees (Kimbrough and Atkinson, 1972; Ellis and
Ellis, 1997; Zhuang, 1995). Zhuang and Korf (1989) reported on roots of a grass. Beside rotting leaf litter, our samples were also collected on rotting Populus twigs.

Hymenoscyphus caudatus may easily be confused with $H$. hyaloexcipulus H.D. Zheng \& W.Y. Zhuang in terms of morphology, but it differs from the latter species in having much narrower ectal excipular cells, and narrower ascospores (Zheng and Zhuang, 2013).

\section{Conflict of Interest}

Authors have declared no conflict of interest.

\section{Authors' Contributions}

The authors contributed equally.

\section{Acknowledgments}

The authors would like to thank Karamanoğlu Mehmetbey University Research Fund (09-YL-15) for its financial support.

\section{References}

Acar İ, Uzun Y, Akata I (2020). Some macrofungi determined in Şemdinli and Yüksekova districts (Hakkari-Turkey). KSU Journal of Agriculture and Nature 23(1): 157-167.

Akata I, Uzun Y, Kaya A (2014). Macromycetes determined in Yomra (Trabzon) district. Turkish Journal of Botany 38(5): 9991012.

Akçay ME (2020). A new record for the mycota of Turkey. Anatolian Journal of Botany 4(1): 8-10.

Aktaş S, Kaşık G, Doğan HH, Öztürk C (2006). Two new taxa records for the macrofungi of Turkey. Turkish Journal of Botany 30(3): 209-212.

Berber O, Uzun Y, Kaya A (2019). Genea lobulata, A new hypogeous ascomycete record for Turkish mycobiota. Süleyman Demirel University Journal of Natural and Applied Sciences 23(3): 922-924.

Çelik A, Uzun Y, Kaya A (2020). Macrofungal biodiversity of Güneysınır district (Konya-Turkey). The Journal of Fungus 11(1): $75-83$.

Doğan HH, Aktaş S (2010). Two new ascomycetes records from Mediterranean part of Turkey. Biological Diversity and Conservation 3(1): 83-86.

Dumort KP, Carpenter SE (1982). Los Hongos de Colombia-VII: Leotiaceae IV. Hymenoscyphus caudatus and related species from Colombia and adjacent regions. Caldasia 13(64): 567-602.

Ellis BM, Ellis PJ (1997). Microfungi on land plants, an identification handbook. Slough-UK: The Richmond publishing Co. Ltd.

Işık H, Türkekul İ (2018). A new addition to Turkish Helotiaceae. Süleyman Demirel University Journal of Natural and Applied Sciences 22(2): 595-597.

İleri R, Uzun Y, Kaya A (2020). Macromycetes of Karadağ (Karaman) and its environs. The Journal of Fungus 11(1): 57-63.

Kaya A (2009). Macrofungi of Huzurlu high plateau (Gaziantep-Turkey). Turkish Journal of Botany 33(6): 429-437.

Kaya A, Uzun Y, Karacan İH (2009). Macrofungi of Göksun (Kahramanmaraş) district. Turkish Journal of Botany 33(2): 131-139.

Kaya A, Uzun Y, Karacan İH, Yakar S (2019). Contributions to the macromycota of Gaziantep province. Kastamonu University Journal of Forestry Faculty 19(3): 329-341.

Keleş A (2019a). New records of Hymenoscyphus, Parascutellinia, and Scutellinia for Turkey. Mycotaxon 134(1): 169-175.

Keleş A (2019b). New records of macrofungi from Trabzon province (Turkey). Applied Ecology and Environmental Research 17(1): 1061-1069.

Kimbrough JW, Atkinson M (1972). Cultural features and imperfect stage of Hymenoscyphus caudatus. American Journal of Botany 59(2): 165-171.

Kirk PM, Cannon PF, Minter DW, Stalpers JA (2008). Dictionary of the fungi. 10th ed. Wallingford, UK: CAB International.

Öztürk Ö, Doğan HH, Şanda MA (2016). Some new additions to Turkish mycobiota from Sakarya region. Biological Diversity and Conservation 9(1): 97-100.

Öztürk Ö, Doğan HH, Yıldırımlı Ş (2010). Macrofungi of Eldivan dağı (Çankırı). The Herb Journal of Systematic Botany 17(2): 141-154.

Sesli E (2019). Lacrymaria hypertropicalis (Guzmán, Bandala \& Montoya) Cortez (Psathyrellaceae): Türkiye mikotası için yeni bir kayıt. Bağbahçe Bilim Dergisi 6(2): 99-102.

Sesli E, Denchev CM (2014). Checklists of the myxomycetes, larger ascomycetes, and larger basidiomycetes in Turkey. 6th ed. Mycotaxon Checklists Online. 136 p. (http://www.mycotaxon.com/resources/checklists/sesli-v106-checklist.pdf) 
Solak MH, Işıloğlu M, Kalmış E, Allı H (2015). Macrofungi of Turkey, Checklist, Vol. 2. İzmir, Turkey: Üniversiteliler Ofset. Türkekul İ, Işık H (2019). Macrofungal biodiversity of Reşadiye (Tokat) district. Acta Biologica Turcica 32(2): 95-101.

Uzun Y, Acar İ, Akçay ME, Akata I (2014). Additions to the Turkish Discomycetes. Turkish Journal of Botany 38(3): 617-622.

Uzun Y, Kaya A, Akçay ME, Demirel K (2010). New additions to the Turkish macromycota from Bingöl province (Turkey). Turkish Journal of Botany 34(1): 63-66.

Yıldız MS, Türkekul İ, Işık H (2019). Macrofungal biodiversity of Pazar (Tokat) district. BEÜ Journal of Science 8(2): $387-395$.

Zheng H, Zhuang W (2013). Four new species of the genus Hymenoscyphus (fungi) based on morphology and molecular data. Science China Life Sciences 56(1): 90-100.

Zhuang WY (1995). Some new species and new records of Discomycetes in China. V. Mycotaxon 56: 31-40.

Zhuang WY, Korf RP (1989). Some new species and new records of Discomycetes in China. III. Mycotaxon 35(2): 297-312. 